\title{
Assessment of Microbial Load of Fasting Foods available in Street Side, Mid- Level Restaurants and High-Level Restaurants during Navratri
}

\author{
Sandip T. Gaikwad*, Vikas Saxena, Dinkar B. Kamble and Ashutosh Upadhyay \\ National Institute of Food Technology Entrepreneurship and Management, \\ Kundli, Haryana, India \\ *Corresponding author
}

\section{A B S T R A C T}

\section{Keywords}

Fasting food, Eateries, NCTD, Shardiya Navratri, Fasting, Street food, Microbiological quality, Food hygiene, Food safety.

\section{Article Info}

Accepted:

24 January 2017

Available Online:

10 February 2017
Street foods and restaurant foods play a significant role in people's day-to-day food options as well as their consistent nutritional requirements are dependent on these foods. As their ever-growing demanding schedule take away the chance to eat homemade food. Due to convenient availability, these eateries foods are one of the primary food choices especially for city people. Over the years, many food-borne diseases have been appeared due to contaminated non-homemade food intake. Navaratri is one of the major fasting time in India. Lots of individuals observe fast during this holy period. Many restaurants and street side stalls offer different kind of fasting food during this season. This study was conducted to analyze the microbiological quality of selected fasting foods which are sold in street side stalls, mid-level restaurants and high-level restaurants during Shardiya Navaratri. This study examined the microbiological quality of four most generally consumed fasting food items of road side carts, mid-level restaurants and high-level restaurants of each district in National Capital Territory of Delhi, India. Total Plate count (TPC), yeast and mold and presence of E coli were determined and observed in this study. The results show that fasting food samples collected from high-level restaurant have less microbial load than the samples collected from street side cart and mid-level restaurant foods. This study specifically highlights the level of microbial loads found in various available non-homemade foods during festive season of Navratri. Finally, this study endorses that some precautionary measures which the administration and food-maker together should follow and maintain the standard sanitary procedure to prepare, cook and handle foods. Implementation of such measures, rules and guidelines on street food vendors and restaurant foods are enormously crucial to maintain the sanitary condition as well as to prevent dispersion of harmful organisms through consumption of contaminated foods.

\section{Introduction}

Food is chemically complicated matrix, which contains many components which are required for the growth of microorganisms. Growth of microorganism in food is serious issue as food is directly consumed and microorganism can enter the body very easily (Makukutu and Guthrie, 1986). Microbial quality depends on the total number of microorganisms present in the food product. Normally, presence of large amount of microorganism in food products is considered to have a low quality and hazardous effects on the health of consumer (ICMSF, 2006). For the health of consumer and quality of the 
product, it is required to have good manufacturing and good handling practices during processing and distribution of food to ensure prevention of contamination along with spoilage (World Health Organization, 2007). Product manufactured with clean and contamination free ingredients with microbe free utensils generally have less microbial load. These practices may independently and collectively help ominously to the overall quality and safety of the product. Now a day, Microbial food safety is a growing public health concern all over the world (ICMSF, 2006).

Microbiologically polluted foodstuff and water are considered as significant means of transportation of food borne diseases all over the globe (WHO, 1999). It was found in numerous studies that food borne illness has been reason for the higher morbidity in all kind of locations urban as well as rural (Haq and Rahman, 1991; Islam et al., 2008; Ram et al., 2007; Sheikh et al., 2002). Among many causes of food borne illnesses major contributors are poor aseptic practices during food manufacturing and the absence of consciousness regarding food safety (WHO, 1999).

Fasting in medical terms is "voluntary abstinence from consuming food for varying lengths of time" (Trepanowski and Bloomer, 2010). It is a rejection of the corporeal requirements of the physique and the emotional desires of the mind. Fasting is the process of reducing overload of body by not consuming food for specific time (Dadeya et al., 2002). Navratri is a sanctified nine-day festival of Hindu religion where individuals all over India worship different nine avatars of Goddess Durga. In Hindu, Mythology it is believed that Goddess Durga had nine incarnations and all those incarnations was having distinct powers. Durga is worshiped every day during Navratri for each female deity (Butcher, 2004). The term 'Navratri' denotes the nine auspicious nights through which Goddess Durga is worshiped and most of the individuals from Hindu religion observe fast. Various kinds of products are consumed and preferred by individuals during this fast. Consumption of grains along with few other products is not allowed during Navratri. Meat and all meat product consumption are totally prohibited. Set of few special ingredients are allowed to the fasting individuals, known as 'Navratri falahar' (Bosu, 1999). Hygiene is considered to be very important criteria for the selection of fasting food products during Navratri (Gaikwad et al., 2017).

The National Capital Territory of Delhi, generally referred as Delhi is a metropolitan city and Indian union territory (The Constitution Act, 1991). It is having area of about 1,484 square kilometers (573 sq mi). Delhi have 11 districts named as North Delhi, West Delhi, Shahdara, South West Delhi, New Delhi, South East Delhi, South Delhi, East Delhi, Central Delhi, North West Delhi, and North East Delhi (Figure 1). Population of Delhi is about 25 million. Delhi is $2^{\text {nd }}$ most populated city in India. It is most crowded metropolitan agglomeration in India and 3rd major urban area in the world (UN Demographic Urban Areas).

The people from all over the India come to Delhi for job and business due to which it is become a city where individuals from every part of the country are residing. During Shardiya Navaratri fasts are observed all over the India. During Navaratri special fasting food products are consumed by the individuals observing fast. Ingredients like buckwheat flour (kittu ka atta), water chestnut flour (singhare $k a$ atta), Sweet potato, fresh fruits and vegetables, some milk products and Euryale ferox (makhanas) are favored as they are light on the abdominal and can be 
digested effortlessly. As Delhi is among largest urban area, many individuals don't have time to prepare food for them so they prefer eating fasting food in eateries. Eateries also provide special cuisine during Navaratri.

People are greatly fascinated to food from eateries like, street foods and restaurant foods. Non-homemade foodstuff is prepared and offered in such a manner that attracts the general public. It is not just regarding the attraction but it is also about the time required to prepare food for consumption (Mosupye and Von, 2000). As a result of such things people from all age groups and professions have to rely on foods from eateries. It is observed in many cases such are not hygienic and can lead to health hazards. To keep the attention of consumer and make more money with a lesser amount of efforts vendors compromise with the quality of food. It was found that people suffer a lot due to consumption of unhygienic foods (Rheinlander, 2008).

In this study restaurants are classified according to food pricing and menu styling. High-end or high level restaurant's food price is high and quality of serving of products is different from mid-level or mid-end restaurants. In high-level restaurants variety of food items are available than mid-level restaurants. In mid-level restaurants fixed and limited items are cooked whether in highlevel restaurants different meal packages are offered including buffet system where minimum 40 food items are included in the menu.

Hygiene level is more strictly maintained in high level restaurants than mid-level restaurants. In developing countries low to mid income earner are higher than high income earner, so basically customer load is higher in mid-level restaurants as good quality foods are cheaper than high end restaurants. Foods are freshly prepared time to time to serve the customer. Low income populace of developing nations meets their nutritive necessities by taking affordable road side foods which have unique and convincing flavor (Ackah et al., 2011; Cross et al., 2007; Muzaffar et al., 2009). The street foods are commonly sold by vendors or hawkers at street side on cart or in a street side small stall. Street vendors are usually economically poor and uneducated. They generally don't have knowledge of food hygiene, treatments, cleanliness, environment, handling, food service, hand washing. In most of the cases they are not aware about source of raw materials and water which they use for food preparation (Bhowmik, 2010). Microbial food borne illness is most important health problem connected with street foods (Biswas et al., 2010).

Food borne illness is common phenomenon in India even more or less every country's common phenomenon where general hygienic precautions are not followed. This study aimed to assess level of microorganisms present in the fasting food offered in different eateries i.e. street side, mid-level restaurants and high-level restaurants in different districts of National Capital Territory of Delhi.

\section{Materials and Method}

Geographical scope for the study was National Capital territory of Delhi. During Shardiya Navaratri same four fasting food item's microbial loads were analyzed for three different level of food vending locations street side stalls, mid-level restaurants and high-level restaurants. Three different eateries, one from each section of street side stalls, mid-level restaurants and high-level restaurant was selected from each district of NCTD for microbial analysis. NCTD have total 11 districts. Eateries for the study were selected randomly. Total $132(44 \times 3)$ samples were collected and studied. 


\section{Collection of samples}

Collection of samples was carried out during Shardiya Navratri $\left(1^{\text {st }}\right.$ October 2016 to $10^{\text {th }}$ October 2016). Samples of Sago Kheer (Sabudana Kheer), Pumpkin Raita (Kaddu ka Raita), Sweet Potato Halwa (Shakarkandi ka Halwa) andBuckwheat flatbread (Kuttu $k i$ poori) were collected from street side carts, mid-level restaurants and high-level restaurant. These four fasting food product was selected on the basis of availability in most of the eateries and their popularity. Minimum 100gm sample per product was collected for analysis. Samples were collected aseptically in presterile poly-bags and sterile bottles, kept in ice-boxes, and were labelled. Samples were then transferred to the laboratory and stored at $4^{\circ} \mathrm{C}$ until analysis. Samples were taken out from freezer and were analyzed when the temperature of the samples were at room temperature.

\section{Coding and labelling}

All samples collected were labelled with specific codes. The districts were coded with number from 1 to 11 and street fasting foods was coded with 'A', Mid-range restaurants was coded with ' $B$ ' and High ranged restaurants was coded with ' $C$ '.

\section{Microbiological analysis}

$10 \mathrm{~g}$ of sample was taken respectively from each sample with a sterile knife. Sterile blender was used for the blending after taking sample for homogenization. Homogenization is done in $100 \mathrm{ml}$ of sterile peptone water. Serial dilution was carried out with $1 \mathrm{~g}$ of each sample to $100,10^{-1}$ and $10^{-2}$ dilutions in saline water $(0.85 \% \mathrm{NaCl} w / \mathrm{v})$ for microbial analysis. Each food sample with one milliliter of $10^{-2}$ dilution was inoculated on Nutrient agar (Total Plate Count), MacConkey agar ( $E$. coli) and Potato dextrose agar (Yeast and
Mold) using pour-plate technique. The plates were incubated under aerobic condition for 24 - 48 hours at $37^{\circ} \mathrm{C}$, with the exclusion of Potato dextrose agar plates which were incubated at $25^{\circ} \mathrm{C}$ for 5 days. Quebec colony counter (Reichert, USA) was used for counting number of colonies. It is stated as colony forming unit per $\mathrm{ml}$ of sample homogenate (cfu/ml) (Clarence et al., 2009).

\section{Results and Discussion}

During Navaratri all eateries offer different kind of products which are consumed by most of the fasting individuals though out NCTD. These eateries provide a solution for the problem of availability of fasting food. Individuals living away from home or people who don't have time to prepare special food for fasting, they can take fasting food in such eateries. These eateries are appreciated due to their taste, availability at the required time. This study was based on analysis of microbial loads of different food items of street side, mid-level restaurants and high-level restaurants. The sample collection was done in 11 districts of NCTD.

Based on observations and interviews with the fasting individuals and sellers of fasting food the mostly consumed food items are selected. There availability in all eateries was also considered while selection. The selected fasting food items, their key ingredients, method of cooking and possible sources of contamination were documented on the basis of observations and interactions with individuals associated with fasting food. Documented data is summarized in table 1.

Sago kheer is a semisolid food product preferred by many individuals for fasting. With higher water content in to the product there are chances of microbial growth but ingredients like sugar which acts as a preservative along with taste and prevent 
growth of many microorganisms. Microbial load of sago kheer prepared at street side, mid-level restaurants and high-level restaurants is given in table 2 .

Total plate count of the fasting food products collected from all street food venders varies from $6.4 \times 10^{2} \mathrm{cfu} / \mathrm{ml}$ to $3.8 \times 10^{2} \mathrm{cfu} / \mathrm{ml}$, While Total Plate count of sago kheer purchased from Mid-level restaurants were in the range of $5.7 \times 10^{2} \mathrm{cfu} / \mathrm{ml}$ to $4.8 \times 10^{2} \mathrm{cfu} / \mathrm{ml}$. The microbial load of sago kheer collected from high level of restaurants was found to be least, which varies from $5.1 \times 10^{2} \mathrm{cfu} / \mathrm{ml}$ to $3.7 \times 10^{2} \mathrm{cfu} / \mathrm{ml}$. Mean of TPC of sago kheer samples collected from street, Mid ranged restaurants and high level restaurants was found to be $6.0 \times 10^{2} \mathrm{cfu} / \mathrm{ml}, 5.3 \times 10^{2} \mathrm{cfu} / \mathrm{ml}$ and $4.1 \times 10^{2} \mathrm{cfu} / \mathrm{ml}$ respectively.

Sago kheer samples collected from street was having highest yeast and mold count which ranges from $2.8 \times 10^{2} \mathrm{cfu} / \mathrm{ml}$ to $1.7 \times 10^{2} \mathrm{cfu} / \mathrm{ml}$. It is followed by mid ranged restaurants ranging from $1.9 \times 10^{2} \mathrm{cfu} / \mathrm{ml}$ to $1.3 \times 10^{2} \mathrm{cfu} / \mathrm{ml}$. It was found that high level restaurants serve sago kheer with least yeast and mold count which ranges from $1.8 \times 10^{2} \mathrm{cfu} / \mathrm{ml}$ to $1.0 \times 10^{2} \mathrm{cfu} / \mathrm{ml}$. The mean of yeast and mold count of sago kheer collected from street, mid ranged restaurants and high level restaurants was found to be $2.1 \times 10^{2} \mathrm{cfu} / \mathrm{ml}$, $1.6 \times 10^{2} \mathrm{cfu} / \mathrm{ml}$ and $1.3 \times 10^{2} \mathrm{cfu} / \mathrm{ml}$, respectively. E. coli was found in about all sago kheer samples collected from street which ranges from $0.25 \times 10^{2} \mathrm{cfu} / \mathrm{ml}$ to $0.39 \times 10^{2} \mathrm{cfu} / \mathrm{ml}$. E. coli was absent in only sago kheer sample collected from street food stall. Two samples $(0.30 \times 102 \mathrm{cfu} / \mathrm{ml}$ and $0.31 \times 102 \mathrm{cfu} / \mathrm{ml})$ of sago kheer from midranged restaurants have presence of E. coli. $E$. coli was not detected in any sago kheer sample from high level restaurants.

Pumpkin raita is creamy product but equally light and refreshing consumed by many individuals observing fast during Shardiya
Navaratri. It is prepared with curd and chopped pumpkin with other ingredients. The microbiological analysis of Pumpkin Raita collected from different street food venders, mid-range restaurant and high range restaurants of 11 different districts of NCTD is given in table 3 .

Total plate count of Pumpkin raita collected from street food vendor, mid-range restaurants and high level restaurants was found to be in range of $2.9 \times 10^{6} \mathrm{cfu} / \mathrm{ml}$ to $8.0 \times 10^{4} \mathrm{cfu} / \mathrm{ml}, \quad 4.8 \times 10^{4} \mathrm{cfu} / \mathrm{ml}$ to $4.8 \times 10^{3} \mathrm{cfu} / \mathrm{ml}$ and $2.7 \times 10^{3} \mathrm{cfu} / \mathrm{ml}$ to $6.0 \times 10^{2} \mathrm{cfu} / \mathrm{ml}$, respectively. Mean of TPC of pumpkin raita manufactured at high level restaurants was found to be least $\left(1.66 \times 10^{3} \mathrm{cfu} / \mathrm{ml}\right)$ followed by high range restaurants $\left(2.09 \times 10^{4} \mathrm{cfu} / \mathrm{ml}\right)$ and street food venders $\left(10.08 \times 10^{5} \mathrm{cfu} / \mathrm{ml}\right)$. Yeast and mold count of pumpkin raita collected from street food venders was found to be in range of $2.2 \times 10^{6} \mathrm{cfu} / \mathrm{ml}$ to $7.4 \times 10^{4} \mathrm{cfu} / \mathrm{ml}$. While midrange restaurants pumpkin raita was in range of $3.9 \times 10^{4} \mathrm{cfu} / \mathrm{ml}$ to $3.9 \times 10^{3} \mathrm{cfu} / \mathrm{ml}$. It was observed that raita from high level restaurant was in range of $3.7 \times 10^{3} \mathrm{cfu} / \mathrm{ml}$ to $5.8 \times 10^{2}$. Mean of yeast and mold count of pumpkin raita manufactured at high-range restaurants was found to be least $1.42 \times 10^{3}$ Followed by mid-range restaurants $\left(1.79 \times 10^{4} \mathrm{cfu} / \mathrm{ml}\right)$ and street food venders $\left(7.98 \times 10^{5} \mathrm{cfu} / \mathrm{ml}\right)$. E. coli is detected in all samples of pumpkin raita collected from street while presence of $E$. coli was there in four samples from mid-range restaurants.

Sweet potato halwa is sweet dish consumed by individuals observing fast during Navaratri. Sweet Potato is loaded with Iron, fiber, and minerals. They are high in vitamins B6 and C. Peanuts are also a rich source of nutrients and minerals. They contain higher protein ratio when compared to any other tree nut varieties available. Microbial load of street, mid-level and high-level restaurant's sweet potato halwa is different. The variation 
of microbial loads is represented in table 4.

Total plate count of sweet potato halwa collected from street vendor, mid-range restaurants and high level restaurants was found to be in range of $9.2 \times 10^{2} \mathrm{cfu} / \mathrm{ml}$ to $5.4 \times 10^{2} \mathrm{cfu} / \mathrm{ml}, \quad 6.2 \times 10^{2} \mathrm{cfu} / \mathrm{ml}$ to $3.2 \times 10^{2}$ $\mathrm{cfu} / \mathrm{ml}$ and $3.4 \times 10^{2} \mathrm{cfu} / \mathrm{ml}$ to $1.6 \times 10^{2} \mathrm{cfu} / \mathrm{ml}$, respectively. Mean of TPC of Sweet Potato Halwa manufactured at high level restaurants was found to be least $\left(2.42 \times 10^{2} \mathrm{cfu} / \mathrm{ml}\right)$ followed by mid-range restaurants $\left(4.58 \times 10^{2}\right.$ $\mathrm{cfu} / \mathrm{ml})$ and street food venders $\left(7.25 \times 10^{2}\right.$ $\mathrm{cfu} / \mathrm{ml})$. Yeast and mold count of sweet potato halwa collected from street food venders was found to be in range of $8.8 \times 10^{2} \mathrm{cfu} / \mathrm{ml}$ to $4.9 \times 10^{2} \mathrm{cfu} / \mathrm{ml}$. Yeast and mold count of samples of sweet potato Halwa collected from mid-range restaurant was in range of $5.8 \times 10^{2} \mathrm{cfu} / \mathrm{ml}$ to $2.8 \times 10^{2} \mathrm{cfu} / \mathrm{ml}$ while it was observed that samples of halwa from high level restaurant was in range of $4.6 \times 10^{2}$ $\mathrm{cfu} / \mathrm{ml}$ to $1.1 \times 10^{2} \mathrm{cfu} / \mathrm{ml}$. Mean of yeast and mold count of sweet potato halwa manufactured at high level restaurants was found to be least $2.27 \times 10^{2} \mathrm{cfu} / \mathrm{ml}$ followed by mid-range restaurants $\left(4.19 \times 10^{2} \mathrm{cfu} / \mathrm{ml}\right)$ and street food venders $\left(6.21 \times 10^{2} \mathrm{cfu} / \mathrm{ml}\right)$. E. coli was not found in any sample of sweet potato halwa from street food stall, mid-range restaurant and high range restaurant.

Buckwheat flatbread is a gluten free fasting food product. This is a Falihar (a food eaten on days of fast in Navratri). As grains are not allowed for fasting individuals, buckwheat is preferred by many people as substitute of grains. It contains 34\% manganese, $28 \%$ copper, $21 \%$ magnesium, $18 \%$ fiber and $17 \%$ phosphorus. It helps to control blood sugar and lower the risk of diabetes, heart disease and high blood pressure. It avoids gallstones in women. Microbial load of Buckwheat flatbread prepared at street side, mid-level restaurants and high-level restaurants is given in table 5 .
Total plate count of buckwheat flatbread collected from street vendor, mid-range restaurants and high level restaurants was found to be in range of $9.6 \times 10^{2} \mathrm{cfu} / \mathrm{ml}$ to $6.9 \times 10^{2} \mathrm{cfu} / \mathrm{ml}, \quad 6.4 \times 10^{2} \mathrm{cfu} / \mathrm{ml}$ to $3.8 \times 10^{2} \mathrm{cfu} / \mathrm{ml}$ and $4.8 \times 10^{2} \mathrm{cfu} / \mathrm{ml}$ to $1.4 \times 10^{2} \mathrm{cfu} / \mathrm{ml}$, respectively. Mean of microbial load of buckwheat flatbread manufactured at high-range restaurants was found to be least $2.91 \times 10^{2} \mathrm{cfu} / \mathrm{ml}$ followed by mid-range restaurants $\left(5.51 \times 10^{2} \mathrm{cfu} / \mathrm{ml}\right)$ and street food venders $\left(8.12 \times 10^{2} \mathrm{cfu} / \mathrm{ml}\right)$. Yeast and mold count of buckwheat flatbread collected from street food venders was found to be in range of $8.8 \times 10^{2} \mathrm{cfu} / \mathrm{ml}$ to $6.1 \times 10^{2} \mathrm{cfu} / \mathrm{ml}$ while from mid-range restaurants was from $5.8 \times 10^{2} \mathrm{cfu} / \mathrm{ml}$ to $2.8 \times 10^{2} \mathrm{cfu} / \mathrm{ml}$. It was observed that flatbread from high level restaurant was in range of $4.1 \times 10^{2} \mathrm{cfu} / \mathrm{ml}$ to $1.0 \times 10^{2} \mathrm{cfu} / \mathrm{ml}$. Mean of yeast and mold count of buckwheat flatbread manufactured at high level restaurants was found to be least $2.37 \times 10^{2} \mathrm{cfu} / \mathrm{ml}$ followed by mid-range restaurants $\left(4.8 \times 10^{2} \mathrm{cfu} / \mathrm{ml}\right)$ and street food venders $\left(7.45 \times 10^{2} \mathrm{cfu} / \mathrm{ml}\right)$. E. coli was not found in any sample of sweet potato halwa from street food stalls except one sample. There was no presence of $E$. coli was found in samples of mid-range restaurants and high range restaurants.

To prevent the occurrence of food borne illnesses, it is important to ensure that foods sold are safe and hygienic. Microbial loads of food sample collected from different places vary because of various reasons. Selected food items from the street, mid-level and high-level restaurants of all districts of NCTD were analyzed for microbial growth. Different types of outcomes were observed by analyzing those foods. Total plate count, yeast and mold count and the presence of $E$. coli were analyzed in three categories of food shops, such as street-side stall, mid-level restaurants, and high-level restaurants. 
Based on this research study, it has been observed that total plate count, yeast, and mold count was present in fasting foods of all the location. The number of micro-organisms detected in street food was found to be higher as compared to the mid-level restaurant and high-level restaurant. The E-coli was majorly found in samples of sago kheer and Pumpkin raita collected from street food stalls and midlevel restaurants. Street fasting food sample have highest microbial count, this is mainly because of its unhygienic food handling and processing practices along with street side dust. Sometimes the food products are covered with a net cover or by cloth but most of the time they are not covered, so flies, road side dust, germs from sneezing, coughing of people and dust bin contaminates the foods. It was found that samples from high level restaurants are having least microbial count due to its good manufacturing practices and the good handling of the product during all stages of processing. The quality of ingredient was also a major contributor for the microbial quality of the product. Most of the chefs were highly trained and had knowledge of processing. There was major difference among the microbial load of the samples collected from street stalls, mid-range restaurants and high level restaurants but at the same time the difference between the microbial load of samples from different districts were negligible.

Study observed that sago kheer was highly contaminated with microbial load in street food samples than middle level and high-level restaurant. Along with processing conditions the microbial quality of ingredients can lead to the higher microbial count of the product.

Almost all street food venders use cheap quality ingredients for processing as there selling rates are cheaper than other types of eateries. Lack of knowledge about good handling of the product can also contribute to the higher microbial load. Least microbial count was found in the samples from high level restaurants. Sago kheer collected from street food was found to have E. coli in about all samples. This is because the use of lowquality water. Water is the main source of $E$. coli to food products.

Microbial count of pumpkin raita was found to be high in all categories. This is mainly because raita is prepared with curd and the water content of raita is very high. Due to high water activity $\left(a_{w}\right)$ the microbial growth is favored. Water activity (Aw) is unbound water molecules available in food and moisture content is equilibrium humidity of the food.

The raita samples collected form street food vendors having high microbial load followed by a mid-level restaurant and high-level restaurant. E. coli was found in all samples of pumpkin raita collected from street food venders. As previously discussed the water is major resource of $E$. coli to food products the presence of $E$. coli in samples from street stalls is mainly because most of venders use local unhygienic water for preparation of raita. E-coli was also detected in some samples of mid-level restaurants, the reason for this is same as that of street food samples. It observed that most of the high level restaurant use purified water for the preparation of food products which leads to $E$. coli free Pumpkin Raita.

In case of microbial load of Sweet Potato halwa samples, it was observed that the total plate count is following trend of all other products; the least count was observed in high level restaurants followed by mid-range restaurants and street food stalls. Halwa is sweet dish made up with sugar. Sugar acts as preservative itself but also provide carbohydrates for the growth of yeast and mold. 
Table.1 Short description of fasting food products selected for study

\begin{tabular}{|c|c|c|c|}
\hline Food item & Key ingredients & Method of cooking & $\begin{array}{c}\text { Possible sources of } \\
\text { contamination }\end{array}$ \\
\hline $\begin{array}{l}\text { Sago Kheer } \\
\text { (Sabudana Kheer), }\end{array}$ & $\begin{array}{l}\text { Sweetened Condensed Milk, Milk, Kesar } \\
\text { (Saffron), Sabudana (Sago), Water, } \\
\text { Kishmish (Raisins), Kaju (Cashew nuts), } \\
\text { Elaichi (Cardamom) Powder, Pure Ghee } \\
\text { (clarified butter) }\end{array}$ & Soaking and Boiling & $\begin{array}{l}\text { Utensils, water, ingredients } \\
\text { processing conditions }\end{array}$ \\
\hline $\begin{array}{l}\text { Pumpkin Raita } \\
\text { (Kaddu ka Raita), }\end{array}$ & $\begin{array}{l}\text { Chopped Pumpkin, Ghee, Jeera (Cumin } \\
\text { Seeds), Finely Chopped Green Chilies, } \\
\text { Sugar, Whisked Curds, Milk, sendha } \\
\text { namak (rock salt) }\end{array}$ & $\begin{array}{l}\text { Frying of Cumin } \\
\text { seed followed by } \\
\text { Addition of other } \\
\text { ingredients and } \\
\text { refrigeration }\end{array}$ & $\begin{array}{l}\text { Utensils, water, cut pieces of } \\
\text { green chili and curd, } \\
\text { Processing conditions }\end{array}$ \\
\hline $\begin{array}{l}\text { Sweet Potato } \\
\text { Halwa (Aloo ka } \\
\text { Halwa), }\end{array}$ & $\begin{array}{l}\text { Sweet Potato, Sugar, clarified butter, Milk, } \\
\text { Raisins, Chopped Cashew nuts, Grounded } \\
\text { Cardamom, Chopped Almonds }\end{array}$ & $\begin{array}{l}\text { Mashing and } \\
\text { cooking }\end{array}$ & $\begin{array}{l}\text { Utensils, Processing } \\
\text { conditions }\end{array}$ \\
\hline $\begin{array}{l}\text { Buckwheat } \\
\text { flatbread. (Kuttu ki } \\
\text { poori) }\end{array}$ & $\begin{array}{l}\text { Kuttu ka Atta (Buckwheat Flour), Medium } \\
\text { Sized Potatoes, Sendha Namak (Rock } \\
\text { Salt), Black Pepper Powder, Clarified } \\
\text { Butter (Ghee), water }\end{array}$ & $\begin{array}{l}\text { Boiling, mashing, } \\
\text { and frying }\end{array}$ & $\begin{array}{l}\text { Utensils, water, potato } \\
\text { processing conditions }\end{array}$ \\
\hline
\end{tabular}

Table.2 Microbial load of sago kheer samples

\begin{tabular}{|c|c|c|c|c|c|c|c|c|c|}
\hline \multirow[t]{2}{*}{ Location } & \multicolumn{3}{|c|}{ TPC (cfu/ml) } & \multicolumn{3}{|c|}{ Yeast and Mold count (cfu/ml) } & \multicolumn{3}{|c|}{ E-coli $(\mathbf{c f u} / \mathbf{m l})$} \\
\hline & $\mathbf{A}$ & B & C & $\mathbf{A}$ & B & C & $\mathbf{A}$ & B & C \\
\hline 1 & $6.4 \times 10^{2}$ & $5.2 \times 10^{2}$ & $3.9 \times 10^{2}$ & $2.0 \times 10^{2}$ & $1.6 \times 10^{2}$ & $1.1 \times 10^{2}$ & $0.25 \times 10^{2}$ & ND & ND \\
\hline 2 & $6.3 \times 10^{2}$ & $5.6 \times 10^{2}$ & $4.2 \times 10^{2}$ & $2.1 \times 10^{2}$ & $1.9 \times 10^{2}$ & $1.4 \times 10^{2}$ & $0.31 \times 10^{2}$ & $0.30 \times 10^{2}$ & ND \\
\hline 3 & $5.9 \times 10^{2}$ & $5.7 \times 10^{2}$ & $5.1 \times 10^{2}$ & $1.7 \times 10^{2}$ & $1.5 \times 10^{2}$ & $1.8 \times 10^{2}$ & $0.38 \times 10^{2}$ & ND & ND \\
\hline 4 & $6.2 \times 10^{2}$ & $5.3 \times 10^{2}$ & $4.6 \times 10^{2}$ & $2.2 \times 10^{2}$ & $1.7 \times 10^{2}$ & $1.3 \times 10^{2}$ & $0.31 \times 10^{2}$ & ND & ND \\
\hline 5 & $5.8 \times 10^{2}$ & $5.1 \times 10^{2}$ & $4.0 \times 10^{2}$ & $2.1 \times 10^{2}$ & $1.5 \times 10^{2}$ & $1.2 \times 10^{2}$ & $0.28 \times 10^{2}$ & ND & ND \\
\hline 6 & $5.9 \times 10^{2}$ & $5.4 \times 10^{2}$ & $3.7 \times 10^{2}$ & $2.0 \times 10^{2}$ & $1.8 \times 10^{2}$ & $1.0 \times 10^{2}$ & $0.39 \times 10^{2}$ & ND & ND \\
\hline 7 & $6.4 \times 10^{2}$ & $4.9 \times 10^{2}$ & $4.3 \times 10^{2}$ & $2.4 \times 10^{2}$ & $1.3 \times 10^{2}$ & $1.3 \times 10^{2}$ & $0.32 \times 10^{2}$ & ND & ND \\
\hline 8 & $7.1 \times 10^{2}$ & $5.1 \times 10^{2}$ & $5.2 \times 10^{2}$ & $2.8 \times 10^{2}$ & $1.6 \times 10^{2}$ & $1.9 \times 10^{2}$ & $0.37 \times 10^{2}$ & ND & ND \\
\hline 9 & $3.8 \times 10^{2}$ & $5.7 \times 10^{2}$ & $4.4 \times 10^{2}$ & $1.8 \times 10^{2}$ & $1.8 \times 10^{2}$ & $1.4 \times 10^{2}$ & ND & ND & ND \\
\hline 10 & $6.3 \times 10^{2}$ & $5.6 \times 10^{2}$ & $4.2 \times 10^{2}$ & $2.2 \times 10^{2}$ & $1.8 \times 10^{2}$ & $1.4 \times 10^{2}$ & $0.36 \times 10^{2}$ & ND & ND \\
\hline 11 & $6.3 \times 10^{2}$ & $4.8 \times 10^{2}$ & $4.5 \times 10^{2}$ & $2.4 \times 10^{2}$ & $1.6 \times 10^{2}$ & $1.5 \times 10^{2}$ & $0.38 \times 10^{2}$ & $0.31 \times 10^{2}$ & ND \\
\hline
\end{tabular}


Table.3 Microbial load of pumpkin raita samples

\begin{tabular}{cccccccccc}
\hline \multirow{2}{*}{ Location } & \multicolumn{2}{c}{ TPC $(\mathrm{cfu} / \mathrm{ml})$} & \multicolumn{2}{c}{ Yeast and Mold count $(\mathrm{cfu} / \mathrm{ml})$} & \multicolumn{2}{c}{ E-coli $(\mathrm{cfu} / \mathrm{ml})$} \\
\cline { 2 - 9 } $\mathbf{1}$ & $\mathbf{A}$ & $\mathbf{B}$ & $\mathbf{C}$ & $\mathbf{A}$ & $\mathbf{B}$ & $\mathbf{C}$ & $\mathbf{A}$ & $\mathbf{B}$ & $\mathbf{C}$ \\
$\mathbf{2}$ & $3.8 \times 10^{4}$ & $4.8 \times 10^{3}$ & $2.6 \times 10^{3}$ & $7.9 \times 10^{4}$ & $3.9 \times 10^{3}$ & $2.1 \times 10^{3}$ & $0.68 \times 10^{2}$ & $0.25 \times 10^{2}$ & ND \\
$\mathbf{3}$ & $6.4 \times 10^{5}$ & $7.2 \times 10^{3}$ & $7.5 \times 10^{2}$ & $2.6 \times 10^{5}$ & $8.2 \times 10^{3}$ & $7.0 \times 10^{2}$ & $0.74 \times 10^{2}$ & $\mathrm{ND}$ & $\mathrm{ND}$ \\
$\mathbf{4}$ & $2.9 \times 10^{6}$ & $6.9 \times 10^{3}$ & $8.6 \times 10^{2}$ & $5.8 \times 10^{5}$ & $6.9 \times 10^{3}$ & $8.9 \times 10^{2}$ & $0.69 \times 10^{2}$ & $\mathrm{ND}$ & $\mathrm{ND}$ \\
$\mathbf{5}$ & $9.4 \times 10^{4}$ & $2.6 \times 10^{4}$ & $4.8 \times 10^{3}$ & $8.3 \times 10^{4}$ & $2.3 \times 10^{4}$ & $3.7 \times 10^{3}$ & $0.83 \times 10^{2}$ & $\mathrm{ND}$ & ND \\
$\mathbf{6}$ & $2.4 \times 10^{5}$ & $3.7 \times 10^{4}$ & $6.0 \times 10^{2}$ & $1.9 \times 10^{5}$ & $3.6 \times 10^{4}$ & $5.8 \times 10^{2}$ & $0.96 \times 10^{2}$ & $0.16 \times 10^{2}$ & ND \\
$\mathbf{7}$ & $1.2 \times 10^{6}$ & $4.8 \times 10^{4}$ & $9.6 \times 10^{2}$ & $1.0 \times 10^{6}$ & $3.9 \times 10^{4}$ & $8.6 \times 10^{2}$ & $0.62 \times 10^{2}$ & 0.27 & ND \\
$\mathbf{8}$ & $3.7 \times 10^{5}$ & $3.9 \times 10^{4}$ & $2.4 \times 10^{3}$ & $3.2 \times 10^{5}$ & $3.2 \times 10^{4}$ & $2.1 \times 10^{3}$ & $0.84 \times 10^{2}$ & ND & ND \\
$\mathbf{9}$ & $2.5 \times 10^{6}$ & $1.8 \times 10^{4}$ & $2.7 \times 10^{3}$ & $2.1 \times 10^{6}$ & $1.5 \times 10^{4}$ & $2.4 \times 10^{3}$ & $0.73 \times 10^{2}$ & ND & ND \\
$\mathbf{1 0}$ & $8.0 \times 10^{4}$ & $2.8 \times 10^{4}$ & $8.1 \times 10^{2}$ & $7.4 \times 10^{4}$ & $2.0 \times 10^{4}$ & $7.7 \times 10^{2}$ & $0.81 \times 10^{2}$ & ND & ND \\
$\mathbf{1 1}$ & $2.6 \times 10^{6}$ & $7.2 \times 10^{3}$ & $9.2 \times 10^{2}$ & $2.2 \times 10^{6}$ & $6.8 \times 10^{3}$ & $8.8 \times 10^{2}$ & $0.67 \times 10^{2}$ & ND & ND
\end{tabular}

Where, $\mathrm{A}=$ Street; $\mathrm{B}=$ Mid-level Restaurants; $\mathrm{C}=$ High Level Restaurants; ND= Not Detected

Table.4 Microbial load of sweet potato halwa samples

\begin{tabular}{|c|c|c|c|c|c|c|c|c|c|}
\hline \multirow{2}{*}{ Locatior } & \multicolumn{3}{|c|}{ TPC (cfu/ml) } & \multicolumn{3}{|c|}{ Yeast and Mold count $(\mathbf{c f u} / \mathbf{m l})$} & \multicolumn{3}{|c|}{ E-coli $(\mathbf{c f u} / \mathbf{m l})$} \\
\hline & $\mathbf{A}$ & B & $\mathbf{C}$ & $\mathbf{A}$ & B & $\mathbf{C}$ & $\mathbf{A}$ & $\mathbf{B}$ & C \\
\hline 1 & $7.6 \times 10^{2}$ & $5.2 \times 10^{2}$ & $3.1 \times 10^{2}$ & $7.1 \times 10^{2}$ & $4.8 \times 10^{2}$ & $2.7 \times 10^{2}$ & ND & ND & ND \\
\hline 2 & $6.3 \times 10^{2}$ & $6.1 \times 10^{2}$ & $2.6 \times 10^{2}$ & $5.9 \times 10^{2}$ & $5.7 \times 10^{2}$ & $2.1 \times 10^{2}$ & ND & ND & ND \\
\hline 3 & $8.1 \times 10^{2}$ & $4.2 \times 10^{2}$ & $3.4 \times 10^{2}$ & $7.8 \times 10^{2}$ & $3.9 \times 10^{2}$ & $2.9 \times 10^{2}$ & ND & ND & ND \\
\hline 4 & $7.9 \times 10^{2}$ & $4.9 \times 10^{2}$ & $2.4 \times 10^{2}$ & $7.5 \times 10^{2}$ & $4.6 \times 10^{2}$ & $2.0 \times 10^{2}$ & ND & ND & ND \\
\hline 5 & $5.6 \times 10^{2}$ & $3.5 \times 10^{2}$ & $1.8 \times 10^{2}$ & $5.3 \times 10^{2}$ & $3.2 \times 10^{2}$ & $2.8 \times 10^{2}$ & ND & ND & ND \\
\hline 6 & $6.8 \times 10^{2}$ & $6.2 \times 10^{2}$ & $1.6 \times 10^{2}$ & $6.1 \times 10^{2}$ & $5.8 \times 10^{2}$ & $1.2 \times 10^{2}$ & $\mathrm{ND}$ & ND & ND \\
\hline 7 & $8.5 \times 10^{2}$ & $4.8 \times 10^{2}$ & $2.0 \times 10^{2}$ & $8.2 \times 10^{2}$ & $4.3 \times 10^{2}$ & $1.7 \times 10^{2}$ & ND & ND & ND \\
\hline 8 & $9.2 \times 10^{2}$ & $4.5 \times 10^{2}$ & $2.8 \times 10^{2}$ & $8.8 \times 10^{2}$ & $4.1 \times 10^{2}$ & $2.2 \times 10^{2}$ & ND & ND & ND \\
\hline 9 & $8.7 \times 10^{2}$ & $3.2 \times 10^{2}$ & $1.7 \times 10^{2}$ & $8.0 \times 10^{2}$ & $2.8 \times 10^{2}$ & $1.1 \times 10^{2}$ & ND & ND & ND \\
\hline 10 & $5.4 \times 10^{2}$ & $3.8 \times 10^{2}$ & $2.2 \times 10^{2}$ & $4.9 \times 10^{2}$ & $3.2 \times 10^{2}$ & $1.7 \times 10^{2}$ & $\mathrm{ND}$ & ND & ND \\
\hline 11 & $5.7 \times 10^{2}$ & $4.0 \times 10^{2}$ & $3.1 \times 10^{2}$ & $5.1 \times 10^{2}$ & $3.7 \times 10^{2}$ & $4.6 \times 10^{2}$ & ND & ND & ND \\
\hline
\end{tabular}

Where, $\mathrm{A}=$ Street; $\mathrm{B}=$ Mid-level Restaurants; $\mathrm{C}=$ High Level Restaurants; ND= Not Detected 
Table.5 Microbial load of buckwheat flatbread samples

\begin{tabular}{|c|c|c|c|c|c|c|c|c|c|}
\hline & \multicolumn{3}{|c|}{ TPC (cfu/ml) } & \multicolumn{3}{|c|}{ Yeast and Mold count (cfu/ml) } & \multicolumn{3}{|c|}{ E-coli $(\mathbf{c f u} / \mathbf{m l})$} \\
\hline ati & $\mathbf{A}$ & $\mathbf{B}$ & $\mathbf{C}$ & $\mathbf{A}$ & $\mathbf{B}$ & $\mathbf{C}$ & $\mathbf{A}$ & $\mathbf{B}$ & $\mathbf{C}$ \\
\hline 1 & $8.2 \times 10^{2}$ & $6.4 \times 10^{2}$ & $3.1 \times 10^{2}$ & $7.8 \times 10^{2}$ & $5.8 \times 10^{2}$ & $2.8 \times 10^{2}$ & ND & ND & ND \\
\hline 2 & $9.1 \times 10^{2}$ & $5.8 \times 10^{2}$ & $3.6 \times 10^{2}$ & $8.6 \times 10^{2}$ & $4.9 \times 10^{2}$ & $3.0 \times 10^{2}$ & ND & ND & ND \\
\hline 3 & $7.6 \times 10^{2}$ & $6.3 \times 10^{2}$ & $3.8 \times 10^{2}$ & $6.8 \times 10^{2}$ & $5.7 \times 10^{2}$ & $3.0 \times 10^{2}$ & ND & ND & ND \\
\hline 4 & $8.5 \times 10^{2}$ & $5.9 \times 10^{2}$ & $1.4 \times 10^{2}$ & $7.6 \times 10^{2}$ & $5.0 \times 10^{2}$ & $1.0 \times 10^{2}$ & ND & ND & ND \\
\hline 5 & $6.9 \times 10^{2}$ & $5.9 \times 10^{2}$ & $2.4 \times 10^{2}$ & $6.1 \times 10^{2}$ & $5.1 \times 10^{2}$ & $1.9 \times 10^{2}$ & ND & ND & ND \\
\hline 6 & $7.3 \times 10^{2}$ & $6.0 \times 10^{2}$ & $1.7 \times 10^{2}$ & $6.7 \times 10^{2}$ & $5.3 \times 10^{2}$ & $1.1 \times 10^{2}$ & ND & ND & ND \\
\hline 7 & $8.1 \times 10^{2}$ & $4.1 \times 10^{2}$ & $3.7 \times 10^{2}$ & $7.5 \times 10^{2}$ & $3.6 \times 10^{2}$ & $3.2 \times 10^{2}$ & ND & ND & ND \\
\hline 8 & $9.6 \times 10^{2}$ & $5.8 \times 10^{2}$ & $1.9 \times 10^{2}$ & $8.8 \times 10^{2}$ & $5.0 \times 10^{2}$ & $1.3 \times 10^{2}$ & ND & ND & ND \\
\hline 9 & $8.4 \times 10^{2}$ & $6.2 \times 10^{2}$ & $2.1 \times 10^{2}$ & $8.0 \times 10^{2}$ & $5.7 \times 10^{2}$ & $1.8 \times 10^{2}$ & ND & ND & ND \\
\hline 10 & $8.3 \times 10^{2}$ & $3.8 \times 10^{2}$ & $3.5 \times 10^{2}$ & $7.3 \times 10^{2}$ & $2.8 \times 10^{2}$ & $2.9 \times 10^{2}$ & $0.29 \times 10^{2}$ & ND & ND \\
\hline 11 & $7.4 \times 10^{2}$ & $4.5 \times 10^{2}$ & $4.8 \times 10^{2}$ & $6.8 \times 10^{2}$ & $3.9 \times 10^{2}$ & $4.1 \times 10^{2}$ & ND & ND & ND \\
\hline
\end{tabular}

Where, $\mathrm{A}=$ Street; $\mathrm{B}=$ Mid-level Restaurants; $\mathrm{C}=$ High Level Restaurants; ND= Not Detected

Fig.1 Districts of national capital territory of Delhi

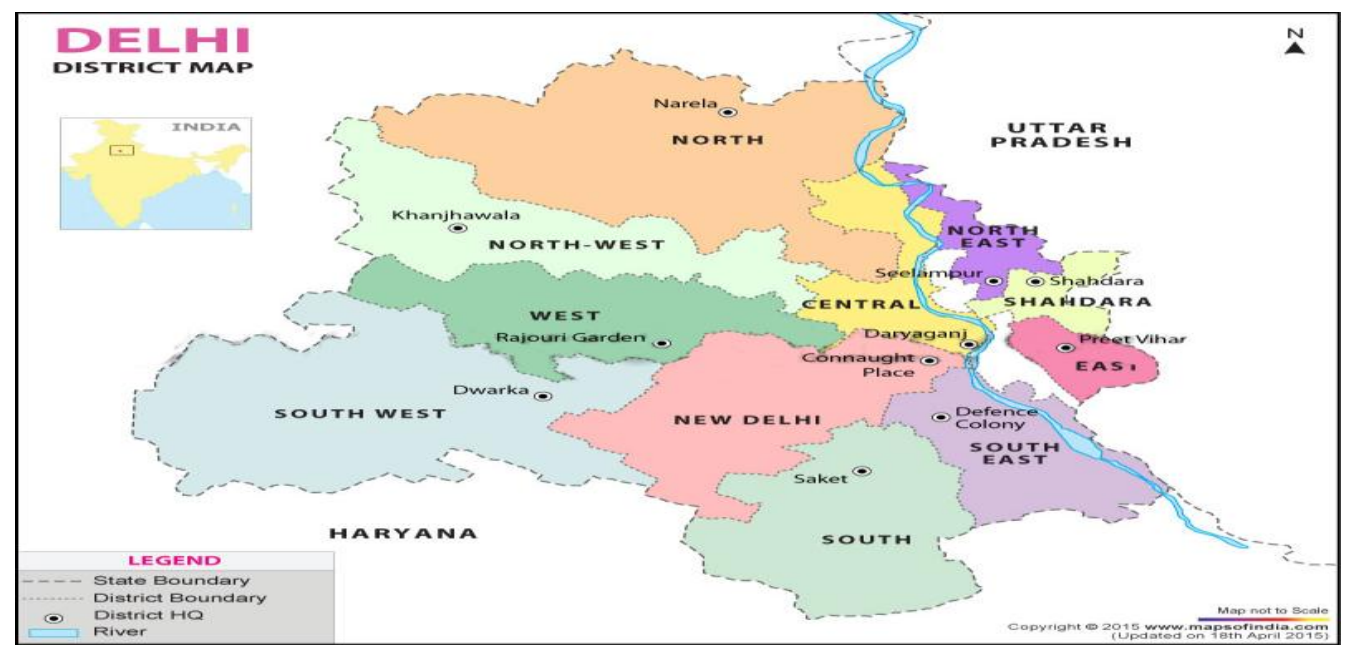

Sweet potato is already sweet in taste, which lead to less addition of sugar for its preparation. E. coli was not found in any sample of sweet potato halwa this is may be due to absence of higher water activity in the halwa. Similarly, E. coli was found to be 
absent in all the samples of buckwheat flatbread. The absence of coliform count in buckwheat poori in all samples is may be because less moisture content and water activity. Other reasons for no coliform count may be the frying temperature of buckwheat flatbread. Same pattern of microbial load of total plate count and yeast and mold count was observed in buckwheat flatbread samples. Overall the microbial load of samples from high-level restaurant foods was lower than street and mid-level restaurant foods.

The present research study has been carried out to investigate and compare the microbial quality of foods collected from street side stalls, mid-level restaurants and high level restaurants. These collected foods were handled appropriately to preserve the food quality before lab testing to obtain accurate microbial results. High microbial load in street foods occur due to improper food handling, unhygienic food preparation and processing, cooking and storage at inappropriate temperature. Government, consumer, food vendors, chef, stewards and all type people should be aware of food hygiene, public health, implications of consuming contaminated foods, causative diseases. Food safety rules and implementation of food regulatory laws in food preparation, serving and preservation should be strongly maintained to avoid contamination problems and food-borne diseases.

Following points should be strongly observed and maintained for future work and further investigative study to improve the food quality, based on this research study on street side foods and restaurant foods:

1. Classification of available non-homemade foods based on their food quality and microbial loads.
2. Ensuring regular inspection and periodical check on these food preparation procedures

3. Continuous lab test and analytical lab analysis to check the unwarranted presence of any new harmful agents in these foods to ensure food safety for consumers.

\section{Acknowledgement}

The authors are thankful to Mr. Saurabh Arya and Mr. Dnyaneshwar Katare for help during this research work.

\section{References}

AOAC. 2000. Official methods of analysis of AOAC International (17th ed. Gaithersburg, MD, USA, AOAC International.

Butcher, M. 2004. Universal Processes of Cultural Change: reflections on the identity strategies of Indian and Australian youth. J. Intercultural Studies, 25(3), 215-231.

Clarence, S.Y., Nwinyi, C. O. and Chinedu, N.S. 2009. Assessment of bacteriological quality of ready to eat food (Meat pie) in Benin City metropolis, Nigeria. African $J$. Microbiol. Res., 3(6): 390-395.

Dadeya, S., Shibal, F., Khurana, C. and Khanna, A. 2002. Effect of religious fasting on intra-ocular pressure. Eye, 16(4): 463-465.

Gaikwad, S.T., Saxena, V., Kamble, D.B. and Upadhyay A. 2017. Investigating consumer preference of college students about food for fasting, GE-Int. J. Management Res., 5(1), 60-74.

Haq, J.A., Rahman, K.M. 1991. Campylobacter jejuni as a cause of acute diarrhea in children: a study at an urban hospital in Bangladesh. J. Trop. Med. Hyg., 94, 50-54.

ICMSF (International Commission on 
Microbial Specification for Foods), 2006. MicroorganismsinFoods5: Microbiological Specifications of Food Pathogens. Clays Ltd. St Ives plc., Bungay Suffolk, UK115-117.

Islam, M.A., Mondol, A.S., Boer, E., Beumer, R.R., Zwietering, M.H., Talukder, K.A., Heuvelink, A.E. 2008. Prevalence and genetic characterization of Shiga toxinproducing Escherichia coli isolates from slaughtered animals in Bangladesh. Appl. Environ. Microbiol., 74: 5414-5421.

Makukutu, C.A., Guthrie, R.K. 1986. Survivalof Escherichia coli in food at hot holding temperature. J. Food Prot., 49: 497-499.

Mosupye, F.M., and Von Holy, A. 2000. Microbiological hazard identification and exposure assessment of street food vending in Johannesburg, South Africa. Int. J. Food Microbiol., 61(2): 137-145.

Ram, P.K., Naheed, A., Brooks, W.A., Hossain, M.A., Mintz, E.D., Breiman, R.F., Luby, S.P., 2007. Risk factors for typhoid fever in a slum in Dhaka, Bangladesh. Epidemiol. Infect., 135, 458-465.

Rheinlander, T., Olsen, M., Bakang, J. A., Takyi, H., Konradsen, F., and Samuelsen, H. 2008. Keeping up appearances: Perceptions of street food safety in urban Kumasi, Ghana. $J$.
Urban Health, 85(6), 952-964.

Sheikh, A., Sugitani, M., Kinukawa, N., Moriyama, M., Arakawa, Y., Komiyama, K., Li, T.C., Takeda, N., Ishaque, S.M., Hasan, M., Suzuki, K., 2002. Hepatitis e virus infection in fulminant hepatitis patients and an apparently healthy population in Bangladesh. Am. J. Trop. Med. Hyg., 66: 721-724.

The Constitution (Sixty-Ninth Amendment) Act. 1991. Ministry of Law and Justice, Government of India. Retrieved 23 November 2014.

Trepanowski, J. F., and Bloomer, R. J. 2010. The impact of religious fasting on human health. Nutrition J., 9(1), 57.

UN Demographic Urban Areas. UN stats. Retrieved 12 December 2016

World Health Organization (WHO). 1999. Food Safety: An Essential Public Health Issue for the New Millennium. Food Safety Programme, Department of Protection of the Human Environment, Cluster of Sustainable Development and Healthy Environments, WHO, Geneva.

World Health Organization. 2007. Quality assurance of pharmaceuticals: a compendium of guidelines and related materials. Good manufacturing practices and inspection (Vol. 2. World Health Organization.

\section{How to cite this article:}

Sandip T. Gaikwad, Vikas Saxena, Dinkar B. Kamble and Ashutosh Upadhyay. 2017. Assessment of Microbial Load of Fasting Foods available in Street Side, Mid-Level Restaurants and High-Level Restaurants during Navratri. Int.J.Curr.Microbiol.App.Sci. 6(2): 1484-1495. doi: http://dx.doi.org/10.20546/ijcmas.2017.602.166 